\title{
Sex differences, gonadal hormones and the fear extinction network: implications for anxiety disorders
}

\author{
Kelimer Lebron-Milad and Mohammed R Milad*
}

\begin{abstract}
Convergent data from rodents and human studies have led to the development of models describing the neural mechanisms of fear extinction. Key components of the now well-characterized fear extinction network include the amygdala, hippocampus, and medial prefrontal cortical regions. These models are fueling novel hypotheses that are currently being tested with much refined experimental tools to examine the interactions within this network. Lagging far behind, however, is the examination of sex differences in this network and how sex hormones influence the functional activity and reactivity of these brain regions in the context of fear inhibition. Indeed, there is a large body of literature suggesting that sex hormones, such as estrogen, do modulate neural plasticity within the fear extinction network, especially in the hippocampus.

After a brief overview of the fear extinction network, we summarize what is currently known about sex differences in fear extinction and the influence of gonadal hormones on the fear extinction network. We then go on to propose possible mechanisms by which sex hormones, such as estrogen, may influence neural plasticity within the fear extinction network. We end with a discussion of how knowledge to be gained from developing this line of research may have significant ramifications towards the etiology, epidemiology and treatment of anxiety disorders.
\end{abstract}

Keywords: menstrual cycle, sex hormones, estrogen, progesterone, estrus cycle, fear extinction

\section{Background}

There are now substantial data indicating that structural, cellular and molecular differences exist between the male and female brains in regions that are important for cognition, memory and affect, such as the hippocampus, amygdala and prefrontal cortex. Some of these differences may have clinical relevance, as marked disparities in disease incidence, manifestation, prognosis and treatment have been observed between the sexes. For example, men have a higher prevalence of conditions that emerge early in development, such as autism, attention deficit hyperactivity disorder and schizophrenia. Women, on the other hand, have a higher prevalence of disorders that emerge in adolescence or adulthood, such as major depression and anxiety disorders. Surprisingly, very little is known about the neural mechanisms that underlie the expression of sex

\footnotetext{
* Correspondence: milad@nmr.mgh.harvard.edu
Department of Psychiatry, Harvard Medical School \& Massachusetts General

* Correspondence: milad@nmr.mgh.harvard.edu
Department of Psychiatry, Harvard Medical School \& Massachusetts General Hospital, Boston, MA, USA
}

(c) 2012 Lebron-Milad and Milad; licensee BioMed Central Ltd. This is an Open Access article distributed under the terms of the Creative

differences in psychiatric disorders. A 2001 report by the Institute of Medicine highlighted the need to conduct scientific studies at the cellular, molecular and whole organism level that take into account sex as a variable to investigate the neural mechanisms that lead to epidemiological differences in psychiatric disorders.

The need to examine sex differences in the network mediating fear learning and its extinction can be surmised from two different perspectives. From a clinical perspective, we need to understand what contributes to the significant epidemiological differences in psychiatric disorders that are characterized by exaggerated fear and anxiety, such as post traumatic stress disorder. From a basic neuroscience perspective, it is essential that we understand how male and female brains differ in processing fundamental neurobiological phenomena such as emotional learning and memory. There is now a clear indication that failure in the function of brain regions that mediate fear learning and fear inhibition may be associated with the psychopathology of anxiety disorders 
[1-5]. Sexual dimorphism in the amygdala, hippocampus and medial prefrontal cortices is well documented [6,7]. These brain regions also contain elevated levels of estrogen receptors [8-10]. Thus, the structural and functional differences in these brain regions between the sexes may explain in part, or contribute to, some of the basic and clinical differences observed between men and women. In examining the literature pertinent to learning and memory, fear conditioning, and fear extinction, it is astonishing to note that of all that we have learned about these processes, less than $2 \%$ of this research has been focused on the female brain (Figure 1).

\section{The fear extinction network: a brief overview}

Review of the fear extinction literature in general is beyond the scope of this article. We direct the reader to some recent reviews on fear extinction that focused on the translational aspects of this line of research [11], the general clinical relevance [12-16] and the molecular machinery of fear extinction [17]. Our review of fear extinction will be brief with the objective of setting the stage for the points we intend to make regarding sex differences in, and estrogen's influence on, the fear extinction network.

\section{Components of the fear extinction network}

Early studies of conditioned fear extinction showed that blockade of N-Methyl-D-aspartic acid (NMDA) receptors within the amygdala impair the extinction of fear potentiated startle [18]. A number of studies subsequently showed that lesion or pharmacological manipulations of the basolateral amygdala (BLA) and the intercalated GABAergic neurons within the amygdala interfere with fear extinction learning [19-21]. Electrophysiological data recorded from the BLA during fear extinction indicate the existence of two neural populations: one signals fear and the other signals fear inhibition or extinction [22]. Thus, in addition to its role in fear acquisition [23], the amygdala appears to also play a critical role in fear extinction [24,25].

In addition to the amygdala, the infralimbic (IL) region of the rat ventromedial prefrontal cortex (vmPFC) appears critical for the consolidation and retrieval of the extinction memory after a delay. Lesions [26-28], pharmacological manipulations [24,29,30] and electrophysiological recording [31] studies implicate the IL in extinction memory consolidation and expression. Moreover, electrical stimulation of IL simulates extinction memory $[32,33]$. Subsequent studies have further supported these findings using different experimental tools, including measuring intrinsic excitability of IL neurons [30,34,35], using metabolic mapping [36], potentiation of thalamic inputs to IL [37], and manipulations of hippocampal inputs to IL $[38,39]$.

Another key structure that plays a role in fear extinction is the hippocampus. While its specific role in fear extinction is currently being investigated, it is likely that the hippocampus learns about the context in which fear learning took place and learns about the context in which extinction learning takes place $[40,41]$. During extinction recall, the hippocampus can, depending on the context, allow the expression of either the fear memory via activation of the amygdala fear neurons, or safety memory via activation of IL neurons [42]. A number of studies have now shown that the interaction between the hippocampus and IL during fear extinction is key to the success of extinction memory consolidation and expression [41,43-45].

Neuroimaging studies have translated these findings to the human brain using comparable fear conditioning paradigms, some of which use contextual manipulations of fear conditioning and extinction [46-49]. Imaging studies began by implicating the human amygdala in fear

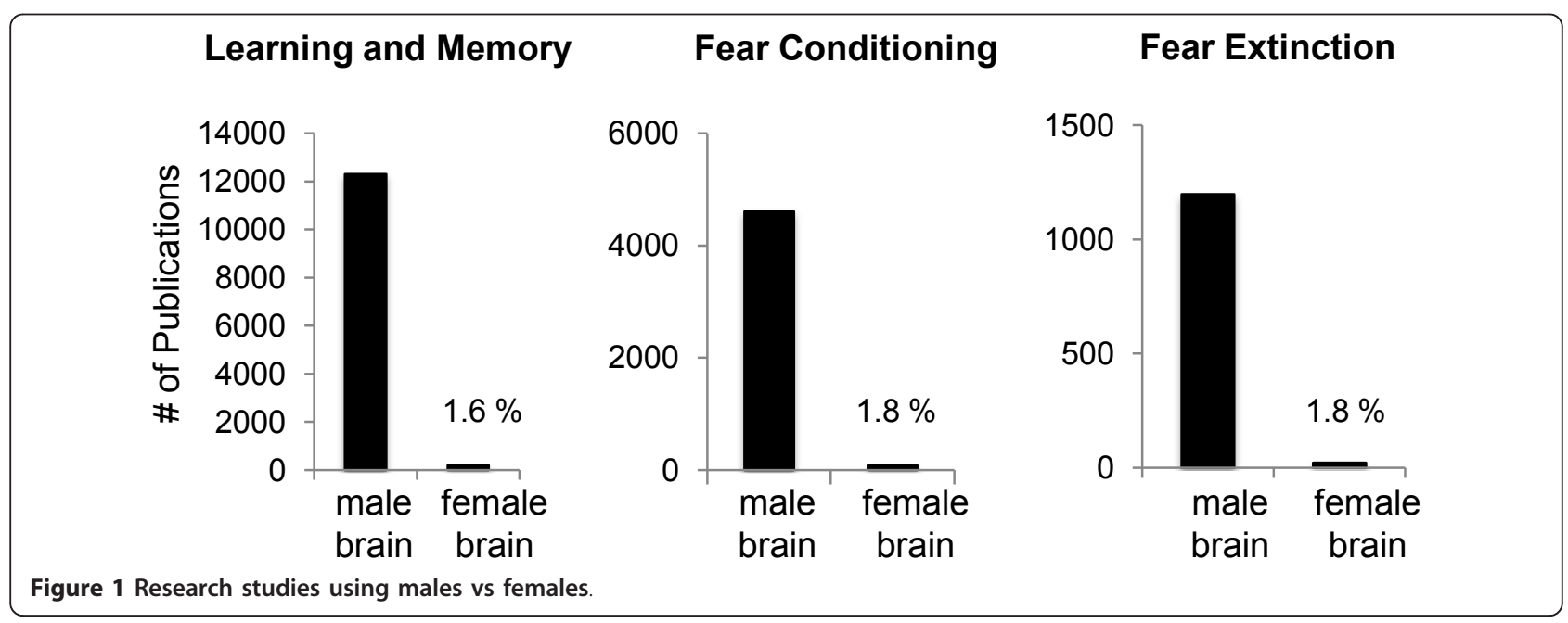


conditioning and also during extinction learning $[46,50,51]$. Recent functional magnetic resonance imaging studies (fMRI) designed specific paradigms to examine extinction recall and found that, like the rat IL, the human vmPFC increased activation to the extinguished cue during extinction recall; the level of activation positively correlates with the extinction recall magnitude $[46,47,51]$. Thickness of the vmPFC is also correlated with magnitude of extinction recall [52,53]. Like the amygdala and vmPFC, activation of the hippocampus during fear extinction is reported in a number of imaging studies during contextual conditioning [48] and extinction memory recall $[47,51]$. Deactivation of the hippocampus at the time of the delivery of the unconditioned stimulus (US) has also been reported in humans [54].

\section{The molecular machinery mediating learning not to fear}

There now exists a large database regarding the molecular machinery involved in fear extinction within the amygdala, hippocampus and IL in rodents. In BLA, interfering with mitogen activated protein kinase (MAPK), phosphoinositide 3-kinase (PI3-K), immediate early genes cfos and early growth response protein 1 (EGR-1) prevented consolidation of extinction $[17,24,41]$. Protein synthesis in BLA is also necessary for fear extinction [55]. Extinction training leads to structural changes in BLA. For example, mRNA for the brain-derived neurotrophic factor (BDNF) is up-regulated [56]. Furthermore, rats with lentiviral-induced reduction in BDNF receptors in the BLA can extinguish normally within a session, but were unable to recall extinction the following day, consistent with a role of BLA in consolidation of extinction [56]. In IL, extinction memory requires NMDA receptor activation [57,58], protein kinase A [17], MAPK [59], cannabinoid receptors [60], and protein synthesis $[17,29]$. In the hippocampus, extinction of context conditioning requires protein synthesis [61] cyclic adenosine monophosphate (c-AMP) [62], BDNF [43] and a number of protein kinases and their regulators [63].

\section{Sex differences during conditioning and its extinction}

A number of studies have investigated differences between females and males in learning and memory using a number of behavioral tasks. For example, females acquire eye-blink conditioning at a faster rate relative to males [64]. In inhibitory avoidance tasks, females outperform males in escaping during a one-way avoidance task and a two-way avoidance task [65]. Studies conducted to examine sex differences in the acquisition of cued and contextual fear conditioning showed that male rodents exhibit increased contextual and cued fear conditioning relative to females [66-70], whereas other studies failed to show sex differences in these learning tasks [71].

Relative to fear acquisition, few studies have investigated potential sex differences during extinction learning and recall $[72,73]$. We showed that sex differences in fear extinction are influenced by the phase of the estrous cycle in female rats and the menstrual cycle in women [74-76]. When not taking cycle phase into consideration, differences in fear extinction recall were not noted in either female rats or in naturally cycling women. When females were divided into low and high endogenous estradiol groups, however, sex differences emerged. During extinction recall, male rats showed comparable levels of extinction retention to female rats with high estradiol; both were significantly higher than females with low estradiol [75]. The same pattern of results was observed in women. That is, men's extinction retention was comparable to that of women with high estradiol; and both groups showed significantly higher levels of extinction retention compared to women with low estradiol [76]. Thus, the lack of sex differences reported in previous studies or the discrepant results between studies may be the result of not taking into consideration the cycle phase of the animals being tested. These data also raise the following question: could sex hormones influence the learning, consolidation and plasticity typically associated with fear extinction in the female brain?

\section{Sex hormones influencing fear extinction in the female rat and in women}

The data reviewed above indicate that sex hormones in rodents and humans may contribute to differences in fear learning and fear extinction. In support of this, estrogen treatment in ovariectomized female rats enhanced the acquisition of fear conditioning [70,77] and fear potentiated startle [78]; though elevated estrogen levels have been associated with reduced contextual conditioning in another study [67]. A few studies have shown that estrogen facilitated the extinction of passive avoidance [79] and conditioned taste aversion [80]. To date, there are few published studies that specifically examined the role of sex hormones on fear extinction learning and its subsequent recall. One exception is Chang et al., (2009), who have recently shown that infusion of estrogen into the hippocampus facilitates extinction of context conditioning and enhances hippocampal long term potentiation (LTP) [81].

We have recently conducted a number of experiments examining how endogenous fluctuations and exogenous manipulations of sex hormones, particularly estrogen and progesterone, influence fear extinction in female rats. A diagram of the natural fluctuations of sex 
hormones during the estrous cycle in rats and the menstrual cycle in women is shown in Figure 2. We observed that naturally cycling females exhibited the least amount of freezing during extinction recall when they underwent extinction learning during the proestrus phase (high estrogen and progesterone) of the estrous cycle [75]. These findings suggest that estrogen and/or progesterone may facilitate the consolidation of extinction learning (Figure 3B). In support of this, systemic pre- or post-extinction administration of estradiol into female rats undergoing extinction learning in the metestrus phase (low estrogen and progesterone) significantly reduced freezing during recall (Figure 4a, b) [75]. Systemic blockade of estrogen receptors alpha $(E R \alpha)$ and estrogen receptor beta $(E R \beta)$ in female rats undergoing extinction in the proestrus phase significantly increased freezing [75]. In a later study, we observed that administration of ER $\beta$ but not ER $\alpha$ agonists were able to facilitate extinction recall in female rats undergoing extinction training in the metestrus phase of the cycle [74]. These data provide strong evidence that cycling sex hormones, estradiol in particular, in female rats do indeed influence extinction consolidation, possibly via the selective activation of the ER $\beta$ receptors.

In women, neuroimaging studies have shown that measures of fear and arousal are associated with changes in hormonal levels throughout the menstrual cycle $[67,82,83]$. Interestingly, increased vmPFC activation was observed in women in the luteal phase relative to those in the early follicular phase of the menstrual cycle while performing a Go-No-Go Task [84], suggesting that estrogen may facilitate the functional activation of the vmPFC. We have conducted an initial psychophysiological study to assess the influence of the menstrual cycle phase on recall of fear extinction in healthy women, and found that natural fluctuations of gonadal hormones do modulate extinction recall [85]. Women with high estrogen exhibited significantly enhanced extinction recall (that is, less fear) relative to women with low estrogen levels [76] (Figure 3A). In a more recent study, we replicated the effect of facilitated extinction recall in women with high estrogen and found that the increased estrogen levels in these women is associated with increased vmPFC, hippocampal and amygdala activation during extinction recall (Figure 5), further supporting the idea that estrogen may be playing a critical role in extinction memory consolidation [74].

\section{How might estrogen modulate extinction recall? Estrogen and its receptors}

In females, estrogen is primarily produced by the ovaries, while in males testosterone is produce by the testis and then aromatized into estrogen [86]. Estrogen can also be synthesized in brain regions, such as the hippocampus [87]. The most potent circulating estrogen is $17 \beta$-estradiol and the most characterized ERs are ER $\alpha$ and ER $\beta$ [88]. These receptors belong to the nuclear receptor superfamily and can be localized in the nucleus as well as in the cytoplasm of the cell [88]. ER $\alpha$ and ER $\beta$ are coded by different genes but share similar DNA-binding and ligand-binding domains. Estrogen binds to either ER $\alpha$ or ER $\beta$ through its estrogen response element DNA binding site. These result in receptor dimerization and subsequence gene transcription [89].

\section{Localization of the estrogen receptors}

Both receptors are located throughout the rostral-caudal extent of the brain and spinal cord, including regions of

\section{Human menstrual cycle}

\section{Rat estrous cycle}

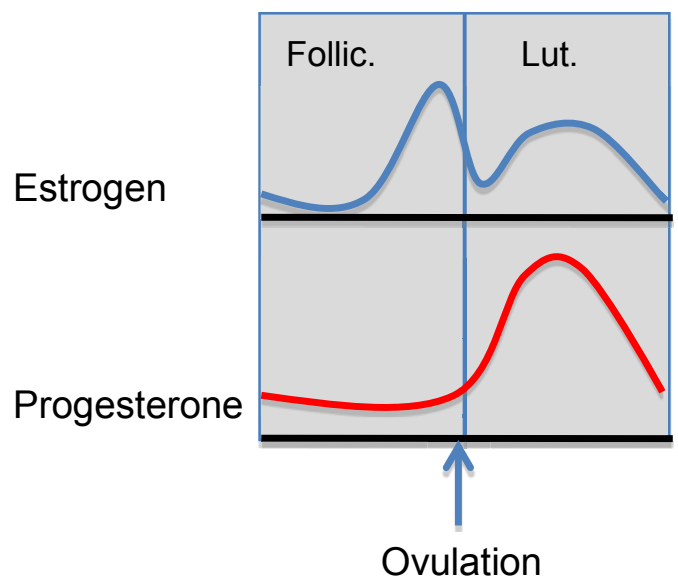

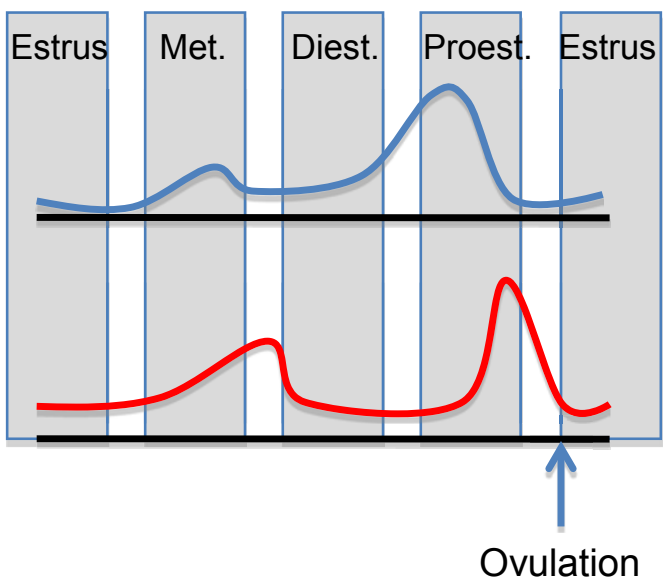

Figure 2 The menstrual cycle and the estrous cycle [164] 


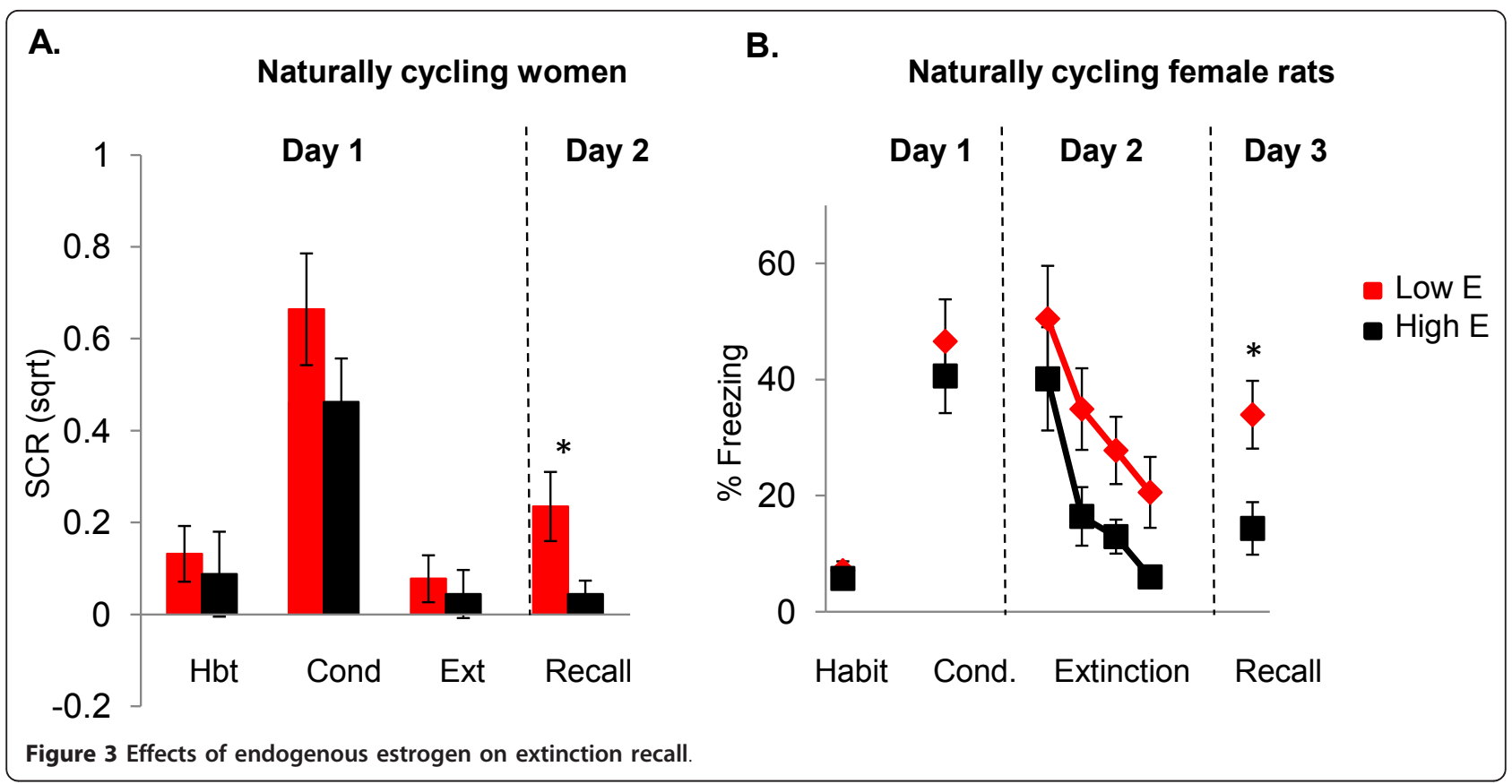

the fear circuitry $[90,91]$. Previous studies have shown that expression of ER $\alpha$ and ER $\beta$ overlap in many brain regions, such as the bed nucleus of the stria terminalis, medial and cortical amygdaloid nuclei, periaqueductal grey and locus coeruleus [91]. However, differences in expression have also been shown where one type of receptor is either expressed alone or at higher concentrations relative to the other. For example, ER $\alpha$ is the predominant receptor expressed in the ventromedial nucleus of the hypothalamus while ER $\beta$ is most prevalent in the hippocampus [92]. ER $\alpha$ and ER $\beta$ are expressed in the amygdala while ER $\beta$ is mostly expressed in PFC [93-95]. Activation of these two types of receptors leads to different behavioral consequences. Accumulating evidence now indicates that selective ER $\beta$ agonists typically exert potent anxiolytic activity when animals were tested in a number of behavioral paradigms $[91,96,97]$. In contrast, selective ER $\alpha$ agonists were found to be anxiogenic and correspondingly increased the hormonal stress response [91].

\section{Sex differences in the estrogen receptors}

$E R \alpha$ and ER $\beta$ have similar distributions in male and female brains, although subcellular distributions of ER to the nucleus, cytoplasm, dendrites and nerve terminals have been reported to be different in male and female human hypothalamus [98]. Although the functional consequences of these differences remain to be determined, this could indicate differential effects of estrogen in the male versus female brains regarding cellular processes, such as neurite extension, synaptic plasticity and mitochondrial energy regulation via mitochondrial ERs.
There is also evidence for sex differences in intracellular signaling, expression of co-regulatory proteins, and in the response of the brain ER/aromatase system to injury [88].

\section{Estrogen-induced molecular and cellular changes}

The influence of estrogen on molecular and cellular changes in the brain has been examined mostly in the hippocampus $[99,100]$ and in the hypothalamus [88]. Hippocampal estrogen enhances synaptogenesis and long-term potentiation (LTP) [101], increases the formation of dendritic spines [102,103], increases cell proliferation [104], and increases neural excitability $[105,106]$. Estrogen-induced LTP in the hippocampus is mediated via synaptic transmission of NMDA receptors [107], specifically through the increased expression of the NR2B subunit [108].

Increased estrogen is also associated with increased BDNF expression in the hippocampus [109,110]. It is possible that estrogen-enhanced extinction memory consolidation may be mediated via increasing BDNF expression in the hippocampus or the vmPFC. Indeed, BDNF expression is critical for successful fear extinction in both rodents and humans [111]. Peters et al. (2010) showed that hippocampal infusion of BDNF before extinction training enhanced extinction memory in an NMDAr dependent process, suggesting that hippocampal BDNF modulates IL activity during the consolidation of extinction memory [112]. Estrogen and BDNF are known to have similar mechanisms of actions, activate the same cascades, and have the same behavioral effects, especially within the hippocampus. For example, both 


\section{Pre Ext.}

A.

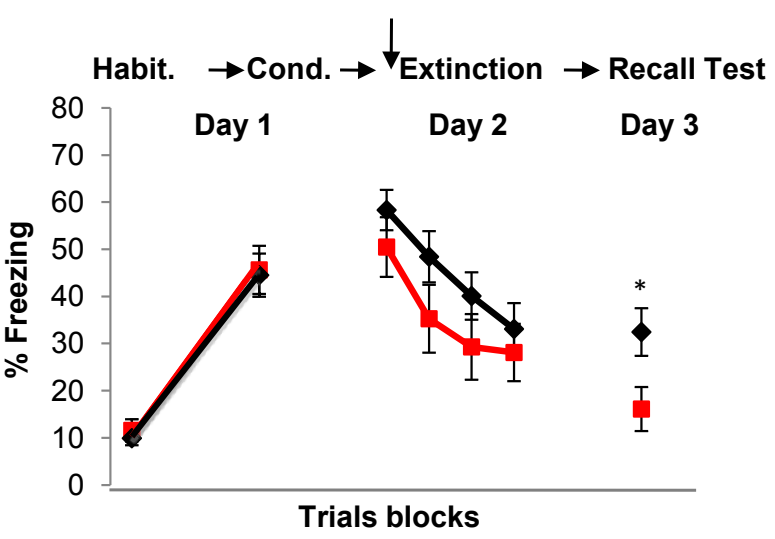

B.

Post Ext

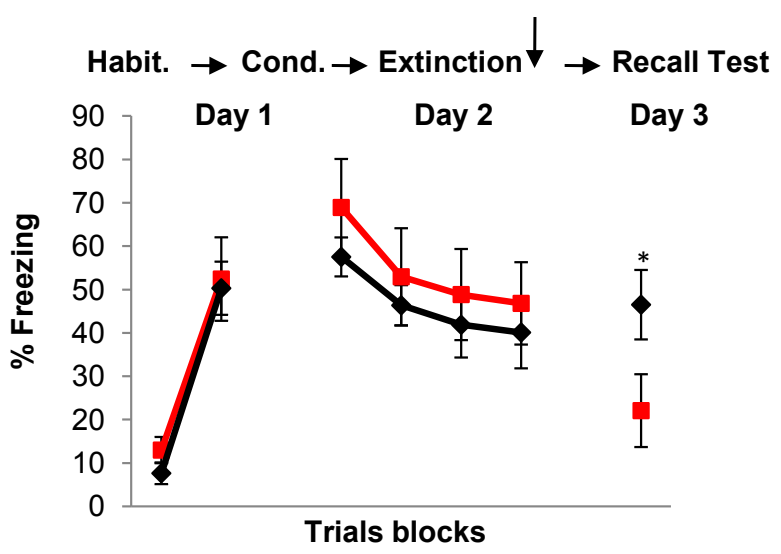

C.

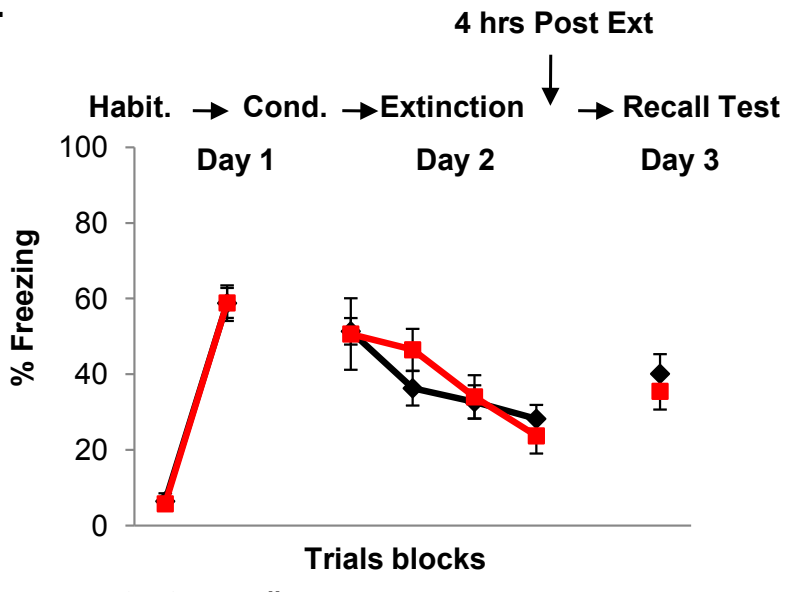

Figure 4 Effects of exogenous estrogen on extinction recall.

estrogen and BDNF enhance hippocampal-dependent learning $[109,110]$. The direct interaction between estrogen and BDNF during fear extinction has not yet been investigated.
Few studies have examined the influence of estrogen on the function of the vmPFC in the rat. Estrogen has been shown to increase spine density in vmPFC [113], preserve the functional integrity of the IL when 


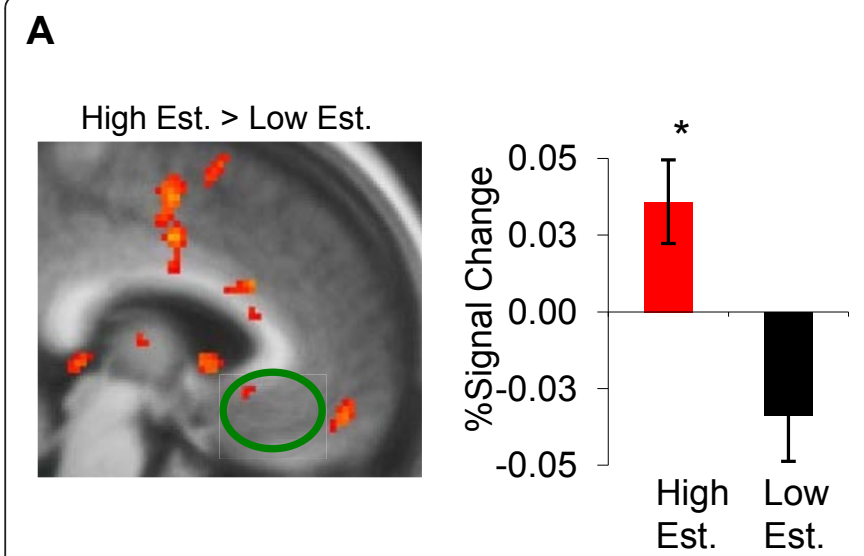

A
B

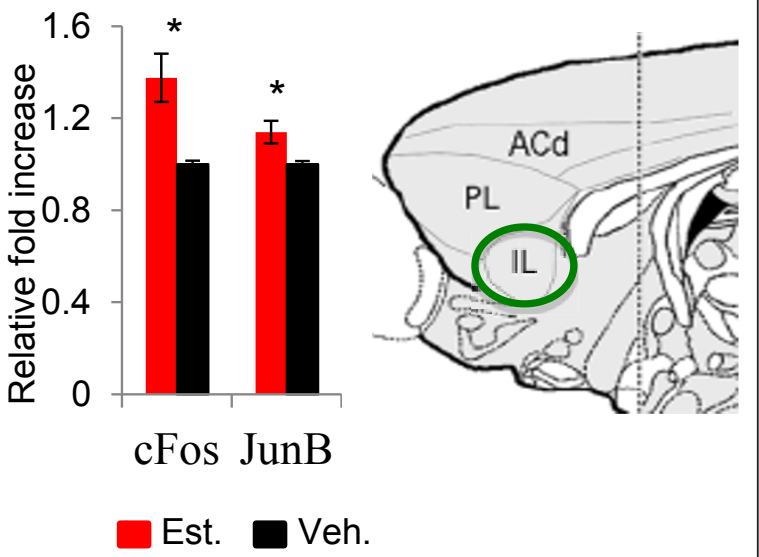

Figure 5 Effects of estrogen in vmPFC activation and gene expression during extinction recall.

subjecting the rats to chronic stress [114], and to enhance working memory [115]. These data indicate that estrogen influences the function of the vmPFC in the rat brain. Markers of neural activity and synaptic plasticity, such as c-Fos, Jun-b and BDNF, have been shown to be modulated by estrogen variance [74,116-118]. Therefore, we propose that estrogen may modulate fear extinction learning and consolidation via its interaction with a number of molecular markers of plasticity, within the fear extinction network.

We recently examined the influence of estradiol administration on $\mathrm{c}$-fos and Jun-b mRNA expression within some components of the fear extinction network. Female rats undergoing fear extinction during the metestrus phase of the cycle (low estrogen) received estradiol immediately post-extinction training and were sacrificed immediately after a brief extinction recall test. The results of this study showed that administration of estradiol after extinction training enhanced c-fos and June-b mRNA expression in IL (Figure 5b) and significantly reduced the expression of both in the amygdala during recall [74]. These data further support the idea that estrogen fluctuations may be a critical modulator of extinction memory consolidation in females. In order to fully understand the role of estrogen in fear extinction, it is necessary to identify the molecular cascades by which estrogen may enhance extinction memory and investigate sex differences in estrogen action within the extinction network.

\section{What about progesterone and testosterone? Progesterone}

Several studies have shown that progesterone administration to ovariectomized female rats facilitates contextual and cued fear conditioning, and enhances cognitive performance in a variety of other behavioral tasks in mice [119]. In healthy young women, administration of progesterone during the early follicular phase (when progesterone and estrogen are at their lowest level) led to increased reactivity in the amygdala while looking at threatening faces [120]. Also, progesterone increased the functional coupling of the amygdala with the mPFC [121], indicating that progesterone influences interactions between the amygdala-PFC circuits. Moreover, progesterone is metabolized into allopregnanolone [122], which acts via $\mathrm{GABA}_{\mathrm{A}}$ receptors and appears to have anxiolytic effects when infused into the amygdala or vmPFC before an elevated plus-maze test and shockprobe burying test $[122,123]$. In other tasks, progesterone facilitates extinction of cocaine self-administration [124]. We have shown that systemic administration of progesterone into female rats (either alone or in conjunction with estrogen) facilitates extinction consolidation [75], suggesting that progesterone appears to also influence the function of brain regions involved in extinction consolidation. Our data gathered in women, however, showed that variance in progesterone levels in two separate cohorts of women did not correlate with extinction recall $[74,76]$. While progesterone's influence on fear extinction may differ across species, it is important to note that we were not able to fully examine the effects of progesterone independent of estrogen. Thus, it remains possible that progesterone may have an effect on fear extinction consolidation in women directly or perhaps by interacting with estrogen. Additional studies are needed to further examine the role of progesterone in fear extinction in women.

\section{Testosterone}

It is established that besides the masculinization/defeminizing role of testosterone during sexual differentiation, 
this hormone is also critical for the modulation of behavioral and physiological responses to anger $[125,126]$. Men demonstrating higher dominance express high levels of testosterone. In male primates, dominance is associated with higher testosterone levels and a decrease in stress response, indicating that dominant males find dominance signals less stressful and are more primed to engage in a dominance challenge $[127,128]$. More interestingly, previous studies have shown that testosterone reduces cortisol response and stress axis reactivity $[129,130]$. Other studies demonstrated that endogenous as well as exogenous testosterone influence neural reactivity to threatening faces in the amygdala and orbitofrontal cortex (OFC) in males, and in the amygdala in women [128,131]. Exogenous testosterone also increases amygdala reactivity to threatening faces, but reduces functional coupling between the amygdala and OFC in middle-aged women, suggesting that the testosterone may regulate interactions between amygdala and OFC [128]. It is important to note that effects of testosterone may be mediated via direct interactions with androgen receptors or via conversion to other steroids. Testosterone is metabolized to dihydrotestosterone (DHT), which also acts via androgen receptors, and to androstanediol that modulates $\mathrm{GABA}_{\mathrm{A}}$ receptor similar to allopregnanolone [132]. Lastly, testosterone is also aromatized into $17 \mathrm{~b}$-estradiol, the most potent type of estradiol, and it has been suggested that most of the effects of testosterone are mediated by estrogen $[133,134]$. Clinical and basic studies are needed to assess the role of testosterone during fear extinction.

\section{Clinical relevance}

Increased expression of inappropriate fear is the hallmark of anxiety disorders [135-138]. A large body of evidence from neuroimaging studies indicates that the neural circuits subserving fear conditioning and extinction are impaired across the different anxiety disorders [12]. For example, post-traumatic stress disorder (PTSD) patients exhibit decreased vmPFC and hippocampal activation along with exaggerated amygdala activation during the processing of emotional stimuli in a wide array of paradigms [139-142]. Experimental extinction is also deficient in PTSD patients [10,143-146]. We have recently shown that fear extinction is deficient in PTSD patients and that such deficiency is associated with aberrant activation of the vmPFC, hippocampus and amygdala (in addition to insula and striatal regions) during fear acquisition, extinction learning and extinction recall $[1,5,54,74]$.

Epidemiological data suggest that the prevalence of anxiety disorders is higher in women relative to men. Women are more likely to develop panic disorder $(8 \%$ vs. $3 \%)$, PTSD (12.5\% vs. $6 \%)$ and generalized anxiety disorder (GAD) (7\% vs. 4\%) (Pigott, 2003; Breslau et al., 1998;Kinrys and Wygant, 2005). Aside from prevalence, women diagnosed with PTSD have longer symptom duration (48 vs. 12 months) [147], have higher symptom severity and functional impairment [148], and have worse quality of life [149]. Women diagnosed with GAD are more likely to develop comorbid psychiatric disorders and have worse prognoses and impairments [150]. In addition to increased prevalence of panic disorder in women, studies also suggest that panic attacks occur more frequently in women relative to men [151]. These findings point to brain-based differences in the processing of emotional stimuli in women compared to men, and suggest that sex hormones, such as estrogen, play a key role in mediating these differences. Indeed, there are some clinical data suggesting that estrogen therapy improves anxiety symptoms in postnatal depression [152], in recurrent postpartum affective disorder [153], and in menopause $[154,155]$. Despite these glaring differences, it is puzzling that so few studies have considered sex differences as a critical variable of interest.

\section{Conclusions}

The data reviewed herein point to clear sex differences in, and clear influence of, sex hormones, especially estrogen, on fear extinction. The data discussed show that sex hormones may have direct effects on the molecular machinery mediating synaptic plasticity in the hippocampus, and the vmPFC during fear extinction. These data also point to significant clinical implications. Future studies need to develop paradigms to test specific hypotheses based on what we know thus far. For example, does estrogen serve a protective function against elevated fear and anxiety? Could transient periods of low estradiol levels be associated with impaired retention of safety memory? In addition, fear extinction in women using oral contraceptives and in menopausal women with and without hormone replacement therapy should be examined. This is especially important given that the use of oral and intrauterine contraceptives is known to reduce endogenous cycling estradiol levels [156]. Moreover, women appear to be vulnerable to developing mood and anxiety disorders during postpartum $[157,158]$ and menopausal periods [159-163] when endogenous estradiol levels are low. Additional studies investigating the effects of cycling sex hormones and exogenous manipulations of these hormones in animal models of fear inhibition could potentially introduce ways to adapt, improve or produce therapies specifically tailored to women.

\section{Abbreviations}

BDNF: brain-derived neurotrophic factor; BLA: basolateral amygdala; CAMP: cyclic adenosine monophosphate; DHT: dihydrotestoterone; EGR-1: early 
growth response protein 1; ERa: estrogen receptors alpha; ERß: estrogen receptor beta; fMRI: functional magnetic resonance neuroimaging; GAD: generalize anxiety disorders; IL: infralimbic; ITC: intercalated GABAergic neurons; LTP: long-term potentiation; MAP kinase: mitogen activated protein; NMDAr: N-Methyl-D-aspartic acid receptor; OFC: orbitofrontal cortex; PI 3kinase: phosphoinositide 3-kinase; PTSD: posttraumatic stress disorders; US: unconditioned stimulus; VMPFC: ventromedial prefrontal cortex

\section{Acknowledgements}

We would like to thank Bronwyn Graham, PhD and Alina Tsareva, BS for helpful comments on this manuscript. MRM is supported by NIH grants K01MH08036 and R01-MH081975 (MGH subcontract), and Department of Defense grant W81XWH-11-2-0079.

\section{Endnotes}

There are no endnotes for this manuscript.

\section{Authors' contributions}

KLM and MRM contributed equally to this manuscript. Both authors read and approved the final manuscript.

\section{Authors' information \\ N/A}

\section{Competing interests}

The authors declare that they have no competing interests.

Received: 27 September 2011 Accepted: 7 February 2012 Published: 7 February 2012

\section{References}

1. Milad MR, Pitman RK, Ellis CB, Gold AB, Shin LM, Lasko NB, Handwerger K, Orr SP, Rauch SL: Neurobiological basis for failure to recall extinction memory in Posttraumatic Stress Disorder. Biol Psychiatry 2009, 66:1075-1082.

2. Milad MR, Rauch SL: The role of the orbitofrontal cortex in anxiety disorders. Ann NY Acad Sci 2007, 1121:546-561.

3. Milad MR, Quirk GJ, Pitman RK, Orr SP, Fischl B, Rauch SL: A role for the human dorsal anterior cingulate cortex in fear expression. Biol Psychiatry 2007, 62:1191-1194.

4. Shin LM, Liberzon I: The neurocircuitry of fear, stress, and anxiety disorders. Neuropsychopharmacology 2010, 35:169-191.

5. Rougemont-Bucking A, Linnman C, Zeffiro TA, Zeidan MA, Lebron-Milad K, Rodriguez-Romaguera J, Rauch SL, Pitman RK, Milad MR: Altered processing of contextual information during fear extinction in PTSD: an fMRI study. CNS Neurosci Ther 2011, 17:227-236.

6. Goldstein JM, Kennedy DN, Caviness VS Jr: Images in neuroscience. Brain development, XI: sexual dimorphism. Am J Psychiatry 1999, 156:352.

7. Goldstein JM, Seidman LJ, Horton NJ, Makris N, Kennedy DN, Caviness VS, Faraone SV, Tsuang MT: Normal sexual dimorphism of the adult human brain assessed by in vivo magnetic resonance imaging. Cereb Cortex 2001, 11:490-497.

8. Montague D, Weickert CS, Tomaskovic-Crook E, Rothmond DA, Kleinman JE, Rubinow DR: Oestrogen receptor alpha localisation in the prefrontal cortex of three mammalian species. J Neuroendocrinol 2008, 20:893-903.

9. Spencer JL, Waters EM, Romeo RD, Wood GE, Milner TA, McEwen BS: Uncovering the mechanisms of estrogen effects on hippocampal function. Front Neuroendocrinol 2008, 29:219-237.

10. Walf AA, Frye CA: A review and update of mechanisms of estrogen in the hippocampus and amygdala for anxiety and depression behavior. Neuropsychopharmacology 2006, 31:1097-1111.

11. Herry C, Ferraguti F, Singewald N, Letzkus JJ, Ehrlich I, Luthi A: Neuronal circuits of fear extinction. Eur J Neurosci 2010, 31:599-612.

12. Graham BM, Milad MR: The study of fear extinction: implications for anxiety disorders. Am J Psychiatry 2011, 168:1255-1265.

13. Choi DC, Rothbaum BO, Gerardi M, Ressler KJ: Pharmacological enhancement of behavioral therapy: focus on posttraumatic stress disorder. Curr Top Behav Neurosci 2010, 2:279-299.

14. Davis M, Myers KM, Chhatwal J, Ressler KJ: Pharmacological treatments that facilitate extinction of fear: relevance to psychotherapy. NeuroRx 2006, 3:82-96.
15. Milad MR, Rauch SL, Pitman RK, Quirk GJ: Fear extinction in rats: implications for human brain imaging and anxiety disorders. Biol Psychol 2006, 73:61-71.

16. Rauch SL, Shin LM, Phelps EA: Neurocircuitry models of posttraumatic stress disorder and extinction: human neuroimaging research-past, present, and future. Biol Psychiatry 2006, 60:376-382.

17. Quirk GJ, Mueller D: Neural mechanisms of extinction learning and retrieval. Neuropsychopharmacology 2008, 33:56-72.

18. Falls WA, Miserendino MJ, Davis M: Extinction of fear-potentiated startle: blockade by infusion of an NMDA antagonist into the amygdala. $J$ Neurosci 1992, 12:854-863.

19. Amano $T$, Unal $C T$, Pare D: Synaptic correlates of fear extinction in the amygdala. Nat Neurosci 2010, 13:489-494.

20. Likhtik E, Popa D, Apergis-Schoute J, Fidacaro GA, Pare D: Amygdala intercalated neurons are required for expression of fear extinction. Nature 2008, 454:642-645.

21. Amir A, Amano T, Pare D: Physiological identification and infralimbic responsiveness of rat intercalated amygdala neurons. J Neurophysiol 2011, 105:3054-3066.

22. Herry C, Ciocchi S, Senn V, Demmou L, Muller C, Luthi A: Switching on and off fear by distinct neuronal circuits. Nature 2008, 454:600-606.

23. Ledoux JE: Emotion circuits in the brain. Annu Rev Neurosci 2000 23:155-184.

24. Myers KM, Davis M: Mechanisms of fear extinction. Mol Psychiatry 2007 12:120-150.

25. Sotres-Bayon F, Quirk GJ: Prefrontal control of fear: more than just extinction. Curr Opin Neurobiol 2010, 20:231-235.

26. Lebron K, Milad MR, Quirk GJ: Delayed recall of fear extinction in rats with lesions of ventral medial prefrontal cortex. Learn Mem 2004, 11:544-548.

27. Sierra-Mercado D, Padilla-Coreano N, Quirk GJ: Dissociable roles of prelimbic and infralimbic cortices, ventral hippocampus, and basolateral amygdala in the expression and extinction of conditioned fear. Neuropsychopharmacology 2011, 36:529-538.

28. Quirk GJ, Russo GK, Barron JL, Lebron K: The role of ventromedial prefrontal cortex in the recovery of extinguished fear. J Neurosci 2000 20:6225-6231

29. Santini E, Ge H, Ren K, Peña de Ortiz S, Quirk GJ: Consolidation of fear extinction requires protein synthesis in the medial prefrontal cortex. $J$ Neurosci 2004, 24:5704-5710.

30. Fontanez-Nuin DE, Santini E, Quirk GJ, Porter JT: Memory for fear extinction requires mGluR5-mediated activation of infralimbic neurons. Cereb Cortex 2011, 21:727-735.

31. Milad MR, Quirk GJ: Neurons in medial prefrontal cortex signal memory for fear extinction. Nature 2002, 420:70-74.

32. Milad MR, Vidal-Gonzalez I, Quirk GJ: Electrical stimulation of medial prefrontal cortex reduces conditioned fear in a temporally specific manner. Behav Neurosci 2004, 118:389-394.

33. Vidal-Gonzalez I, Vidal-Gonzalez B, Rauch SL, Quirk GJ: Microstimulation reveals opposing influences of prelimbic and infralimbic cortex on the expression of conditioned fear. Learn Mem 2006, 13:728-733.

34. Santini E, Porter JT: M-type potassium channels modulate the intrinsic excitability of infralimbic neurons and regulate fear expression and extinction. J Neurosci 2010, 30:12379-12386.

35. Santini E, Quirk GJ, Porter JT: Fear conditioning and extinction differentially modify the intrinsic excitability of infralimbic neurons. J Neurosci 2008, 28:4028-4036.

36. Barrett D, Shumake J, Jones D, Gonzalez-Lima F: Metabolic mapping of mouse brain activity after extinction of a conditioned emotional response. J Neurosci 2003, 23:5740-5749.

37. Herry C, Garcia R: Behavioral and paired-pulse facilitation analyses of long-lasting depression at excitatory synapses in the medial prefrontal cortex in mice. Behav Brain Res 2003, 146:89-96.

38. Deschaux O, Motanis H, Spennato G, Moreau JL, Garcia R: Re-emergence of extinguished auditory-cued conditioned fear following a subconditioning procedure: effects of hippocampal and prefrontal tetanic stimulations. Neurobiol Learn Mem 2011, 95:510-518.

39. Deschaux O, Thevenet A, Spennato G, Arnaud C, Moreau JL, Garcia R: Lowfrequency stimulation of the hippocampus following fear extinction impairs both restoration of rapid eye movement sleep and retrieval of extinction memory. Neuroscience 2010, 170:92-98. 
40. Bouton ME, Westbrook RF, Corcoran KA, Maren S: Contextual and temporal modulation of extinction: behavioral and biological mechanisms. Biol Psychiatry 2006, 60:352-360.

41. Corcoran KA, Quirk GJ: Recalling safety: cooperative functions of the ventromedial prefrontal cortex and the hippocampus in extinction. CNS Spectr 2007, 12:200-206.

42. Corcoran KA, Maren S: Factors regulating the effects of hippocampal inactivation on renewal of conditional fear after extinction. Learn Mem 2004, 11:598-603.

43. Peters J, Dieppa-Perea LM, Melendez LM, Quirk GJ: Induction of fear extinction with hippocampal-infralimbic BDNF. Science 2010, 328:1288-1290.

44. Corcoran KA, Quirk GJ: Recalling safety: cooperative functions of the ventromedial prefrontal cortex and the hippocampus in extinction. CNS Spectr 2007, 12:200-206.

45. Garcia R, Spennato G, Nilsson-Todd L, Moreau JL, Deschaux O: Hippocampal low-frequency stimulation and chronic mild stress similarly disrupt fear extinction memory in rats. Neurobiol Learn Mem 2008, 89:560-566.

46. Phelps EA, Delgado MR, Nearing Kl, Ledoux JE: Extinction learning in humans: role of the amygdala and vmPFC. Neuron 2004, 43:897-905

47. Kalisch R, Korenfeld E, Stephan KE, Weiskopf N, Seymour B, Dolan RJ: Context-dependent human extinction memory is mediated by a ventromedial prefrontal and hippocampal network. J Neurosci 2006, 26:9503-9511

48. Alvarez RP, Biggs A, Chen G, Pine DS, Grillon C: Contextual fear conditioning in humans: cortical-hippocampal and amygdala contributions. J Neurosci 2008, 28:6211-6219.

49. Baas JM, Nugent M, Lissek S, Pine DS, Grillon C: Fear conditioning in virtual reality contexts: a new tool for the study of anxiety. Biol Psychiatry 2004, 55:1056-1060.

50. LaBar KS, Gatenby JC, Gore JC, Ledoux JE, Phelps EA: Human amygdala activation during conditioned fear acquisition and extinction: a mixedtrial fMRI study. Neuron 1998, 20:937-945.

51. Milad MR, Wright Cl, Orr SP, Pitman RK, Quirk GJ, Rauch SL: Recall of fear extinction in humans activates the ventromedial prefrontal cortex and hippocampus in concert. Biol Psychiatry 2007, 62:446-454.

52. Milad MR, Quinn BT, Pitman RK, Orr SP, Fischl B, Rauch SL: Thickness of ventromedial prefrontal cortex in humans is correlated with extinction memory. Proc Natl Acad Sci USA 2005, 102:10706-10711.

53. Hartley CA, Fischl B, Phelps EA: Brain structure correlates of individual differences in the acquisition and inhibition of conditioned fear. Cereb Cortex 2011, 21:1954-1962.

54. Linnman C, Rougemont-Bucking A, Beucke JC, Zeffiro TA, Milad MR: Unconditioned responses and functional fear networks in human classical conditioning. Behav Brain Res 2011, 221:237-245.

55. Kim J, Park S, Lee S, Choi S: Amygdala depotentiation ex vivo requires mitogen-activated protein kinases and protein synthesis. Neuroreport 2009, 20:517-520.

56. Chhatwal JP, Stanek-Rattiner L, Davis M, Ressler KJ: Amygdala BDNF signaling is required for consolidation but not encoding of extinction. Nat Neurosci 2006, 9:870-872.

57. Burgos-Robles A, Vidal-Gonzalez I, Santini E, Quirk GJ: Consolidation of fear extinction requires NMDA receptor-dependent bursting in the ventromedial prefrontal cortex. Neuron 2007, 53:871-880.

58. Sotres-Bayon F, Diaz-Mataix L, Bush DE, LeDoux JE: Dissociable roles for the ventromedial prefrontal cortex and amygdala in fear extinction: NR2B contribution. Cereb Cortex 2009, 19:474-482.

59. Hugues $\mathrm{S}$, Deschaux O, Garcia R: Postextinction infusion of a mitogenactivated protein kinase inhibitor into the medial prefrontal cortex impairs memory of the extinction of conditioned fear. Learn Mem 2004, 11:540-543.

60. Lin HC, Mao SC, Su CL, Gean PW: The role of prefrontal cortex CB1 receptors in the modulation of fear memory. Cereb Cortex 2009, 19:165-175.

61. Li L, Boddul SV, Patil SS, Zheng JF, An G, Hoger H, Lubec G: Proteins linked to extinction in contextual fear conditioning in the C57BL/6J mouse. Proteomics 2011, 11:3706-3724.

62. Wang Z, Phan T, Storm DR: The type 3 adenylyl cyclase is required for novel object learning and extinction of contextual memory: role of cAMP signaling in primary cilia. J Neurosci 2011, 31:5557-5561.
63. Radulovic J, Tronson NC: Molecular specificity of multiple hippocampal processes governing fear extinction. Rev Neurosci 2010, 21:1-17.

64. Dalla C, Shors TJ: Sex differences in learning processes of classical and operant conditioning. Physiol Behav 2009, 97:229-238.

65. Dalla C, Edgecomb C, Whetstone AS, Shors TJ: Females do not express learned helplessness like males do. Neuropsychopharmacology 2008, 33:1559-1569.

66. Maren S, De Oca B, Fanselow MS: Sex differences in hippocampal longterm potentiation (LTP) and Pavlovian fear conditioning in rats: positive correlation between LTP and contextual learning. Brain Res 1994, 661:25-34.

67. Gupta RR, Sen S, Diepenhorst LL, Rudick CN, Maren S: Estrogen modulates sexually dimorphic contextual fear conditioning and hippocampal longterm potentiation (LTP) in rats(1). Brain Res 2001, 888:356-365.

68. Wiltgen BJ, Sanders MJ, Behne NS, Fanselow MS: Sex differences, context preexposure, and the immediate shock deficit in Pavlovian context conditioning with mice. Behav Neurosci 2001, 115:26-32.

69. Aguilar R, Gil L, Gray JA, Driscoll P, Flint J, Dawson GR, Gimenez-Llort L, Escorihuela RM, Fernandez-Teruel A, Tobena A: Fearfulness and sex in F2 Roman rats: males display more fear though both sexes share the same fearfulness traits. Physiol Behav 2003, 78:723-732.

70. Jasnow AM, Schulkin J, Pfaff DW: Estrogen facilitates fear conditioning and increases corticotropin-releasing hormone mRNA expression in the central amygdala in female mice. Horm Behav 2006, 49:197-205.

71. Wiltgen BJ, Sanders MJ, Ferguson C, Homanics GE, Fanselow MS: Trace fear conditioning is enhanced in mice lacking the delta subunit of the GABAA receptor. Learn Mem 2005, 12:327-333.

72. Baran SE, Armstrong CE, Niren DC, Hanna JJ, Conrad CD: Chronic stress and sex differences on the recall of fear conditioning and extinction. Neurobiol Learn Mem 2009, 91:323-332.

73. Baran SE, Armstrong CE, Niren DC, Conrad CD: Prefrontal cortex lesions and sex differences in fear extinction and perseveration. Learn Mem 2010, 17:267-278.

74. Zeidan MA, Igoe SA, Linnman C, Vitalo A, Levine JB, Klibanski A, Goldstein JM, Milad MR: Estradiol modulates medial prefrontal cortex and amygdala activity during fear extinction in women and female rats. Biol Psychiatry 2011, 70:920-927.

75. Milad MR, Igoe SA, Lebron-Milad K, Novales JE: Estrous cycle phase and gonadal hormones influence conditioned fear extinction. Neuroscience 2009, 164:887-895.

76. Milad MR, Zeidan MA, Contero A, Pitman RK, Klibanski A, Rauch SL, Goldstein JM: The influence of gonadal hormones on conditioned fear extinction in healthy humans. Neuroscience 2010, 168:652-658.

77. Morgan MA, Pfaff DW: Effects of estrogen on activity and fear-related behaviors in mice. Horm Behav 2001, 40:472-482.

78. Hiroi R, Neumaier JF: Differential effects of ovarian steroids on anxiety versus fear as measured by open field test and fear-potentiated startle. Behav Brain Res 2006, 166:93-100.

79. Rivas-Arancibia S, Vazquez-Pereyra F: Hormonal modulation of extinction responses induced by sexual steroid hormones in rats. Life Sci 1994, 54: PL363-367.

80. Yuan DL, Chambers KC: Estradiol accelerates extinction of a conditioned taste aversion in female and male rats. Horm Behav 1999, 36:1-16.

81. Chang YJ, Yang CH, Liang YC, Yeh CM, Huang CC, Hsu KS: Estrogen modulates sexually dimorphic contextual fear extinction in rats through estrogen receptor beta. Hippocampus 2009, 19:1142-1150.

82. Cahill L: Sex- and hemisphere-related influences on the neurobiology of emotionally influenced memory. Prog Neuropsychopharmacol Biol Psychiatry 2003, 27:1235-1241

83. Goldstein JM, Jerram M, Poldrack R, Ahern T, Kennedy DN, Seidman LJ, Makris N: Hormonal cycle modulates arousal circuitry in women using functional magnetic resonance imaging. J Neurosci 2005, 25:9309-9316.

84. Protopopescu X, Pan H, Altemus M, Tuescher O, Polanecsky M, McEwen B Silbersweig D, Stern E: Orbitofrontal cortex activity related to emotional processing changes across the menstrual cycle. Proc Natl Acad Sci USA 2005, 102:16060-16065

85. Milad MR, Goldstein JM, Orr SP, Wedig MM, Klibanski A, Pitman RK, Rauch SL: Fear conditioning and extinction: influence of sex and menstrual cycle in healthy humans. Behav Neurosci 2006, 120:1196-1203.

86. Celotti F, Melcangi RC, Negri-Cesi P, Poletti A: Testosterone metabolism in brain cells and membranes. J Steroid Biochem Mol Biol 1991, 40:673-678. 
87. Fester L, Prange-Kiel J, Jarry H, Rune GM: Estrogen synthesis in the hippocampus. Cell Tissue Res 2011, 345:285-294.

88. Gillies GE, McArthur S: Estrogen actions in the brain and the basis for differential action in men and women: a case for sex-specific medicines. Pharmacol Rev 2010, 62:155-198.

89. Tsai MJ, O'Malley BW: Molecular mechanisms of action of steroid/thyroid receptor superfamily members. Annu Rev Biochem 1994, 63:451-486.

90. Weiser MJ, Foradori CD, Handa RJ: Estrogen receptor beta activation prevents glucocorticoid receptor-dependent effects of the central nucleus of the amygdala on behavior and neuroendocrine function. Brain Res 2010, 1336:78-88.

91. Weiser MJ, Foradori CD, Handa RJ: Estrogen receptor beta in the brain: from form to function. Brain Res Rev 2008, 57:309-320

92. Mitra SW, Hoskin E, Yudkovitz J, Pear L, Wilkinson HA, Hayashi S, Pfaff DW, Ogawa S, Rohrer SP, Schaeffer JM, McEwen BS, Alves SE: Immunolocalization of estrogen receptor beta in the mouse brain: comparison with estrogen receptor alpha. Endocrinology 2003, 144:2055-2067.

93. Kritzer MF: Regional, laminar, and cellular distribution of immunoreactivity for ER alpha and ER beta in the cerebral cortex of hormonally intact, adult male and female rats. Cereb Cortex 2002, 12:116-128.

94. Zhang JQ, Cai WQ, Su BY, Zhou de S: Immunocytochemical localization of estrogen receptor beta in the rat brain. Shi Yan Sheng Wu Xue Bao 2002 35:15-20.

95. Osterlund M, Kuiper GG, Gustafsson JA, Hurd YL: Differential distribution and regulation of estrogen receptor-alpha and -beta mRNA within the female rat brain. Brain Res Mol Brain Res 1998, 54:175-180.

96. Krezel W, Dupont S, Krust A, Chambon P, Chapman PF: Increased anxiety and synaptic plasticity in estrogen receptor beta -deficient mice. Proc Natl Acad Sci USA 2001, 98:12278-12282.

97. Imwalle DB, Gustafsson JA, Rissman EF: Lack of functional estrogen receptor beta influences anxiety behavior and serotonin content in female mice. Physiol Behav 2005, 84:157-163.

98. Kruijver FP, Balesar R, Espila AM, Unmehopa UA, Swaab DF: Estrogen receptor-alpha distribution in the human hypothalamus in relation to sex and endocrine status. J Comp Neurol 2002, 454:115-139.

99. Scharfman HE, Hintz TM, Gomez J, Stormes KA, Barouk S, MalthankarPhatak GH, McCloskey DP, Luine VN, Maclusky NJ: Changes in hippocampal function of ovariectomized rats after sequential low doses of estradiol to simulate the preovulatory estrogen surge. Eur J Neurosci 2007, 26:2595-2612.

100. Smith CC, Vedder LC, McMahon LL: Estradiol and the relationship between dendritic spines, NR2B containing NMDA receptors, and the magnitude of long-term potentiation at hippocampal CA3-CA1 synapses. Psychoneuroendocrinology 2009, 34(Suppl 1):S130-S142.

101. McEwen B: Estrogen actions throughout the brain. Recent Prog Horm Res 2002, 57:357-384.

102. Murphy DD, Cole NB, Greenberger V, Segal M: Estradiol increases dendritic spine density by reducing GABA neurotransmission in hippocampal neurons. J Neurosci 1998, 18:2550-2559.

103. Good M, Day M, Muir JL: Cyclical changes in endogenous levels of oestrogen modulate the induction of LTD and LTP in the hippocampal CA1 region. Eur J Neurosci 1999, 11:4476-4480.

104. Tanapat P, Hastings NB, Gould E: Ovarian steroids influence cell proliferation in the dentate gyrus of the adult female rat in a dose- and time-dependent manner. J Comp Neurol 2005, 481:252-265.

105. Foy MR, Xu J, Xie X, Brinton RD, Thompson RF, Berger TW: 17beta-estradiol enhances NMDA receptor-mediated EPSPs and long-term potentiation. $J$ Neurophysiol 1999, 81:925-929.

106. Terasawa E, Timiras PS: Electrical activity during the estrous cycle of the rat: cyclic changes in limbic structures. Endocrinology 1968, 83:207-216.

107. Smith CC, MCMahon LL: Estradiol-induced increase in the magnitude of long-term potentiation is prevented by blocking NR2B-containing receptors. J Neurosci 2006, 26:8517-8522.

108. Smith CC, MCMahon LL: Estrogen-induced increase in the magnitude of long-term potentiation occurs only when the ratio of NMDA transmission to AMPA transmission is increased. J Neurosci 2005, 25:7780-7791.
109. Scharfman HE, Maclusky NJ: Similarities between actions of estrogen and BDNF in the hippocampus: coincidence or clue? Trends Neurosci 2005, 28:79-85.

110. Scharfman HE, MacLusky NJ: Estrogen and brain-derived neurotrophic factor (BDNF) in hippocampus: complexity of steroid hormone-growth factor interactions in the adult CNS. Front Neuroendocrinol 2006, 27:415-435.

111. Soliman F, Glatt CE, Bath KG, Levita L, Jones RM, Pattwell SS, Jing D, Tottenham N, Amso D, Somerville L, Voss HU, Glover G, Ballon DJ, Liston C, Teslovich T, Van Kempen T, Lee FS, Casey BJ: A genetic variant BDNF polymorphism alters extinction learning in both mouse and human. Science 2010, 327:863-866.

112. Peters J, Dieppa-Perea LM, Melendez LM, Quirk GJ: Induction of fear extinction with hippocampal-infralimbic BDNF. Science 2010, 328:1288-1290.

113. Shansky RM, Hamo C, Hof PR, Lou W, McEwen BS, Morrison JH: Estrogen promotes stress sensitivity in a prefrontal cortex-amygdala pathway. Cereb Cortex 2010, 20:2560-2567.

114. Gerrits M, Westenbroek C, Koch T, Grootkarzijn A, Ter Horst GJ: Increased limbic phosphorylated extracellular-regulated kinase 1 and 2 expression after chronic stress is reduced by cyclic 17beta-estradiol administration. Neuroscience 2006, 142:1293-1302.

115. Sinopoli KJ, Floresco SB, Galea LA: Systemic and local administration of estradiol into the prefrontal cortex or hippocampus differentially alters working memory. Neurobiol Learn Mem 2006, 86:293-304.

116. Lokuge S, Frey BN, Foster JA, Soares CN, Steiner M: The rapid effects of estrogen: a mini-review. Behav Pharmacol 2010, 21:465-472

117. Smith CC, Vedder LC, MCMahon LL: Estradiol and the relationship between dendritic spines, NR2B containing NMDA receptors, and the magnitude of long-term potentiation at hippocampal CA3-CA1 synapses. Psychoneuroendocrinology 2009, 34(Suppl 1):S130-142

118. Fan L, Hanbury R, Pandey SC, Cohen RS: Dose and time effects of estrogen on expression of neuron-specific protein and cyclic AMP response element-binding protein and brain region volume in the medial amygdala of ovariectomized rats. Neuroendocrinology 2008, 88:111-126.

119. Frye CA, Walf AA: Progesterone enhances learning and memory of aged wildtype and progestin receptor knockout mice. Neurosci Lett 2010, 472:38-42.

120. Derntl B, Windischberger C, Robinson S, Lamplmayr E, Kryspin-Exner I, Gur RC, Moser E, Habel U: Facial emotion recognition and amygdala activation are associated with menstrual cycle phase. Psychoneuroendocrinology 2008, 33:1031-1040.

121. van Wingen GA, Ossewaarde L, Backstrom T, Hermans EJ, Fernandez G: Gonadal hormone regulation of the emotion circuitry in humans. Neuroscience 2011, 191:38-45.

122. Engin $E$, Treit $D$ : The anxiolytic-like effects of allopregnanolone vary as a function of intracerebral microinfusion site: the amygdala, medial prefrontal cortex, or hippocampus. Behav Pharmacol 2007, 18:461-470.

123. Akwa Y, Purdy RH, Koob GF, Britton KT: The amygdala mediates the anxiolytic-like effect of the neurosteroid allopregnanolone in rat. Behav Brain Res 1999, 106:119-125.

124. Jackson LR, Robinson TE, Becker JB: Sex differences and hormonal influences on acquisition of cocaine self-administration in rats. Neuropsychopharmacology 2006, 31:129-138.

125. Peterson CK, Harmon-Jones E: Anger and testosterone: evidence that situationally-induced anger relates to situationally-induced testosterone. Emotion 2011.

126. Mazur A: The role of testosterone in male dominance contests that turn violent. Soc Biol 2006, 53:24-29.

127. Sapolsky RM: The influence of social hierarchy on primate health. Science 2005, 308:648-652.

128. Stanton SJ, Wirth MM, Waugh CE, Schultheiss OC: Endogenous testosterone levels are associated with amygdala and ventromedial prefrontal cortex responses to anger faces in men but not women. Biol Psychol 2009, 81:118-122.

129. Rubinow DR, Roca CA, Schmidt PJ, Danaceau MA, Putnam K, Cizza G, Chrousos G, Nieman L: Testosterone suppression of CRH-stimulated cortisol in men. Neuropsychopharmacology 2005, 30:1906-1912. 
130. Hermans EJ, Putman P, Baas JM, Gecks NM, Kenemans JL, van Honk J: Exogenous testosterone attenuates the integrated central stress response in healthy young women. Psychoneuroendocrinology 2007, 32:1052-1061.

131. van Wingen G, Mattern C, Verkes RJ, Buitelaar J, Fernandez G: Testosterone reduces amygdala-orbitofrontal cortex coupling. Psychoneuroendocrinology 2010, 35:105-113.

132. Frye CA, Koonce CJ, Edinger KL, Osborne DM, Walf AA: Androgens with activity at estrogen receptor beta have anxiolytic and cognitiveenhancing effects in male rats and mice. Horm Behav 2008, 54:726-734.

133. Sharpe RM: The roles of oestrogen in the male. Trends Endocrinol Metab 1998, 9:371-377.

134. Jones ME, Boon WC, Proietto J, Simpson ER: Of mice and men: the evolving phenotype of aromatase deficiency. Trends Endocrinol Metab 2006, 17:55-64.

135. Pitman RK, Shin LM, Rauch SL: Investigating the pathogenesis of posttraumatic stress disorder with neuroimaging. J Clin Psychiatry 2001, 62(Suppl 17):47-54.

136. Rothbaum BO, Schwartz AC: Exposure therapy for posttraumatic stress disorder. Am J Psychother 2002, 56:59-75.

137. Rothbaum $\mathrm{BO}$, Davis $\mathrm{M}$ : Applying learning principles to the treatment of post-trauma reactions. Ann NY Acad Sci 2003, 1008:112-121.

138. Rauch SL, Shin LM, Whalen PJ, Pitman RK: Neuroimaging and the neuroanatomy of PTSD. CNS Spectr 1998, 3:30-41.

139. Bremner JD: Alterations in brain structure and function associated with post-traumatic stress disorder. Semin Clin Neuropsychiatry 1999, 4:249-255.

140. Gilbertson MW, Shenton ME, Ciszewski A, Kasai K, Lasko NB, Orr SP, Pitman RK: Smaller hippocampal volume predicts pathologic vulnerability to psychological trauma. Nat Neurosci 2002, 5:1242-1247.

141. Shin LM, Orr SP, Carson MA, Rauch SL, Macklin ML, Lasko NB, Peters PM, Metzger LJ, Dougherty DD, Cannistraro PA, Alpert NM, Fischman AJ, Pitman RK: Regional cerebral blood flow in the amygdala and medial prefrontal cortex during traumatic imagery in male and female Vietnam veterans with PTSD. Arch Gen Psychiatry 2004, 61:168-176.

142. Shin LM, Shin PS, Heckers S, Krangel TS, Macklin ML, Orr SP, Lasko N, Segal E, Makris N, Richert K, Levering J, Schacter DL, Alpert NM, Fischman AJ, Pitman RK, Rauch SL: Hippocampal function in posttraumatic stress disorder. Hippocampus 2004, 14:292-300.

143. Orr SP, Roth WT: Psychophysiological assessment: clinical applications for PTSD. J Affect Disord 2000, 61:225-240.

144. Jovanovic T, Norrholm SD, Blanding NQ, Davis M, Duncan E, Bradley B, Ressler KJ: Impaired fear inhibition is a biomarker of PTSD but not depression. Depress Anxiety 2010, 27:244-251.

145. Orr SP, Metzger L, Lasko NB, Macklin ML, Peri T, Pitman RK: De novo conditioning in trauma-exposed individuals with and without posttraumatic stress disorder. J Abnorm Psychol 2000, 109:290-298.

146. Milad MR, Orr SP, Lasko NB, Chang Y, Rauch SL, Pitman RK: Presence and acquired origin of reduced recall for fear extinction in PTSD: results of a twin study. J Psychiatr Res 2008, 42:515-520.

147. Breslau N, Davis GC, Andreski P, Peterson EL, Schultz LR: Sex differences in posttraumatic stress disorder. Arch Gen Psychiatry 1997, 54:1044-1048.

148. Seedat S, Stein DJ, Carey PD: Post-traumatic stress disorder in women: epidemiological and treatment issues. CNS Drugs 2005, 19:411-427.

149. Holbrook TL, Hoyt DB, Stein MB, Sieber WJ: Gender differences in longterm posttraumatic stress disorder outcomes after major trauma: women are at higher risk of adverse outcomes than men. J Trauma 2002, 53:882-888.

150. Bakish D: The patient with comorbid depression and anxiety: the unmet need. J Clin Psychiatry 1999, 60(Suppl 6):20-24.

151. Reed V, Wittchen HU: DSM-IV panic attacks and panic disorder in a community sample of adolescents and young adults: how specific are panic attacks? J Psychiatr Res 1998, 32:335-345.

152. Gregoire AJ, Kumar R, Everitt B, Henderson AF, Studd JW: Transdermal oestrogen for treatment of severe postnatal depression. Lancet 1996, 347:930-933.

153. Sichel DA, Cohen LS, Robertson LM, Ruttenberg A, Rosenbaum JF: Prophylactic estrogen in recurrent postpartum affective disorder. Biol Psychiatry 1995, 38:814-818.

154. Arpels JC: The female brain hypoestrogenic continuum from the premenstrual syndrome to menopause. A hypothesis and review of supporting data. J Reprod Med 1996, 41:633-639.
155. Best NR, Rees MP, Barlow DH, Cowen PJ: Effect of estradiol implant on noradrenergic function and mood in menopausal subjects. Psychoneuroendocrinology 1992, 17:87-93.

156. Taneepanichskul S, Patrachai S: Effects of long-term treatment with depot medroxy progesterone acetate for contraception on estrogenic activity. J Med Assoc Thai 1998, 81:944-946.

157. Altshuler LL, Hendrick V, Cohen LS: Course of mood and anxiety disorders during pregnancy and the postpartum period. J Clin Psychiatry 1998, 59(Suppl 2):29-33.

158. Altshuler LL, Hendrick V, Cohen LS: Course of mood and anxiety disorders during pregnancy and the postpartum period. J Clin Psychiatry 1998, 59(Suppl 2):29-33.

159. Schnatz PF, Whitehurst SK, O'Sullivan DM: Sexual dysfunction, depression, and anxiety among patients of an inner-city menopause clinic. $J$ Womens Health (Larchmt) 2010, 19:1843-1849.

160. Schnatz PF, Whitehurst SK, O'Sullivan DM: Sexual dysfunction, depression, and anxiety among patients of an inner-city menopause clinic. $J$ Womens Health (Larchmt) 2010, 19:1843-1849.

161. Schmidt PJ, Rubinow DR: Sex hormones and mood in the perimenopause. Ann N Y Acad Sci 2009, 1179:70-85.

162. Schweckendiek J, Klucken T, Merz CJ, Tabbert K, Walter B, Ambach W, Vaitl D, Stark R: Weaving the (neuronal) web: fear learning in spider phobia. Neuroimage 2011, 54:681-688.

163. Harsh V, Meltzer-Brody S, Rubinow DR, Schmidt PJ: Reproductive aging, sex steroids, and mood disorders. Harv Rev Psychiatry 2009, 17:87-102.

164. Becker JB, Arnold AP, Berkley KJ, Blaustein JD, Eckel LA, Hampson E, Herman JP, Marts S, Sadee W, Steiner M, Taylor J, Young E: Strategies and methods for research on sex differences in brain and behavior. Endocrinology 2005, 146:1650-1673.

doi:10.1186/2045-5380-2-3

Cite this article as: Lebron-Milad and Milad: Sex differences, gonadal hormones and the fear extinction network: implications for anxiety disorders. Biology of Mood \& Anxiety Disorders 2012 2:3.

\section{Submit your next manuscript to BioMed Central and take full advantage of:}

- Convenient online submission

- Thorough peer review

- No space constraints or color figure charges

- Immediate publication on acceptance

- Inclusion in PubMed, CAS, Scopus and Google Scholar

- Research which is freely available for redistribution

Submit your manuscript at www.biomedcentral.com/submit
C) Biomed Central 